\title{
ENGAGING WITH MAL(E)FUNCTIONS: GENDER AND ENVIRONMENTAL CRISIS IN DAPHNE MARLATT'S ANA HISTORIC
}

\author{
By Carolyn Krahn
}

Daphne Marlatt's novel Ana Historic presents a female-oriented version of historical events not based on male-centered modes of representation. Marlatt fictionalizes aspects of historical and literary documents to carve out a space for an imagined female history that counters masculine production- based narratives previously written about the logging camps of British Columbia. Ana Historic provides a concise look at previous representations of resources and women, which offers insight into how these issues inform a contemporary viewpoint regarding natural resources. Moreover, if the environmental crisis we are experiencing globally is a result of industrialization, have women been manufactured in a similar fashion? And if so, how can North Americans attempt to counter environmental crisis from a societal perspective that is heavily implicated in upholding patriarchal structures? The answer extends beyond mere syllogism, and into the complicated realm of capital: both monetary and social. Revisiting Ana Historic in our current moment of environmental uncertainty reflects the interconnected relationship between so-called natural spaces and engendered representation. This causes an identity crisis for landscapes and gender, leading to the manipulation of these spaces by established patriarchal institutions and industrializing structures. This represents an extension beyond the consideration of women as "Mother Nature" and relates specifically to their manipulation by men into resources that further male capital. Marlatt's transformation of the forest into a manufactured product mimics her transformation of the female protagonists into appropriately functioning wives and mothers. Marlatt's main protagonists Ana, Ina, Annie resist manufacture and become the monsters of male-functions. The transformation of landscapes and women involves 
looking the forest as represented in the natural environment, the sawmill, and the finished product. The malfunction of the proper male functioning in the novel is what I come to label as mal(e)functions. The term mal(e)functions, while embodying the simultaneity of two words also represents the non male-oriented spaces in the novel; that of the forest and the female protagonists. The split in the term also represents the fissures of malecentered narratives where women and environmental consciousness can exist.

Marlatt uses the theoretical apparatus of ecriture feminine to write against of patriarchy purported in Jacques Lacan's "Law of the Father." Lacan's "Law of the Father" explains the phallus as a privileged signifier of that mark in which the role of the logos is joined with the advent of desire (288). For Lacan, words become inextricable from the phallic representation creating a linguistic environment which is presided over by the dominant patriarchal force upon recognition that the female does not have a phallus, and therefore must seek one out from a male (290). The emphasis on Lacan's phallic discourse echoes heavily in Ana Historic. Marlatt must acknowledge the phallus and the male gaze in order to demonstrate the way that these patriarchal theoretical constructions can be challenged and manipulated. Marlatt writes her female protagonists in response to this phallocentric discourse which breaks the female characters in her novel into two categories: those who submit to the patriarchal modes of representation, and those who resist it. The submission to the male patriarch not only occurs between genders in Marlatt's text, but also includes the submission of the forest space to the male centers of industry. Marlatt represents trees not as an embodiment of the male, virile identity but rather something organic, and therefore, must be manufactured by the dominant male entity.

The ability to understand Ana Historic in the context of a women-inclusive history involves dealing with the language that Marlatt employs. Marlatt continually emphasizes a relationship between the relationship of the female body to language, and the manufacture of the forest. The relationship between gender and resources is a 
relationship established by Hélène Cixous' version of ecriture feminine although not explicitly stated. Cixous believed that feminine writing would usher in an alternative way of relating to the world where language "writes itself, where it dreams, where it invents new worlds" (79). Revolutionizing language offers a way to reconsider political and capital; an understanding that has been previously dictated by a presiding patriarchal linguistic space. Cixous' "new world" could be modified to include a space where landscape and environmental features can exist separate from development and manufacture, offering a positive relationship with politics and capital: a reciprocal relationship heavily emphasized by those involved with sustainable building development. Keith Green and Jill LeBihan suggest that" Marlatt's writing participates in an ecriture feminine, a collection of discourses that struggle with the apparent and damaging split between a woman's body and her location in the structures of language" (436). This analogy works well to highlight the tradition of ecriture feminine while showcasing the absences created by the split in the body, and the splitting of trees. Marlatt's positions the character of Annie as attempting to trace a womeninclusive history based on historical information regarding an "Ana Richards" who lived in the Hastings settlement in British Columbia in the 1800s. Most historical writing of this period tends to heavily emphasize the masculine logging industry. An example of this includes M. Allerdale Grainger's Woodsmen of the West which gives an account of a logging camp in the early 1900s. Grainger's text critiques the totalizing masculine structures inherent in the logging industry, but ultimately must invoke the virile, robust masculine tropes in order to do so. Marlatt counters this by focusing on the feminine as opposed to the masculine interpretation of history. Annie relates the character to her own matriarchal history pertaining to her own mother when she reveals "I-na, I-no-longer, $\mathrm{i}$ can't turn you into a story, there is this absence here, where the words stop" (11). Annie lacks the language necessary to describe her mother at this point in the narrative. This split between the (m)other becomes further expanded further down the page when she 
describes "this crumbling apart of words. 'true, real.' you who is you or me. she. a part struck off from me. apart. separated" (11). Annie speaks in lower-case words, identifying her statements as those of little importance, an importance would have been indicated by the presence of the upper-case. In this case the language represents a diminished capacity of the speaker to claim agency for herself. The separations of language, and Annie's separation from her mother Ina, simultaneously act as examples of the absences created by the lack of a women-identified history. The deliberate subversion of the patriarchal modes of language with the term mal(e)functions emphasizes how deep the implications of patriarchal language are. The malfunction of the women in Marlatt's novel can only be measured by how far they appear to deviate from the male-function.

Understanding how mal(e)functions apply to Ana Historic involves tracing its use through the three main stages of resource production, namely: the natural space, the sawmill and the finished product. The forest is the space that has not been inhabited by the loggers. The natural space is as a utopic space where women can exist free of male dominion. Marlatt draws the parallels between the capitalist male-dominated nature, and the nature untouched by males, when she refers to these two opposing spaces early on in the novel stating "those woods men worked in, building powerlines and clearing land for subdivision. those woods the boys on the rest of the block had claimed as theirs'(12). Marlatt then radically opposes the male perspective of the woods with a woman's: “[E]xcept for that part directly behind the garden [that the boys hadn't claimed as theirs], that part her sisters called the Old Wood, moulted and softened with years of needle drift, tea brown, and the cedar stump in the middle where they nestled in a womb" (12). The space of the Old Wood provides a place where women and nature can commune outside the influence of patriarchal control. While critics would align this section of dialogue with an ecofeminist perspective, they would be mistaken to stop at a superficial analogy. Marlatt is not pairing women with nature to show the organic, biological, relationship between the two, she is pairing them to demonstrate the extent of male manipulation of 
environmental/ bodily landscapes. Where the two theoretical approaches meet is through the discussion of the Mother, or Mother Nature as she is exhibited in this space, prior to the control of the male-functions.

What Marlatt is hinting at is a type of matriarchal community that has not yet suffered matricide by the infringing patriarch. The discussion of matriarch is taken up by Luce Irigaray in her discussion of the bodily encounter with the mother asserting that "As for us, it is a matter of urgency not to submit to a desubjectivized social role, that of the mother, governed by an order subordinated to a division of labour-man produces/woman reproduces- which confines us to mere function" (qtd. in Whitford 42). The malefunctions have not yet been allowed to assume control over Mother Nature, and at Irigaray's urging should not be allowed to assume control over women either. Marlatt describes Ana Richards as being "at home only with things without language (birds, trees)" (32). Men do not have control over the landscape of the Old Wood, and consequently do not have control over the language to speak for it either. This affords women a sense of escapism within the forest spaces unadulterated by industry. Marlatt advocates a pre-linguistic and pre-discursive space in which men cannot assume verbal domination over women through language. The image of the stain of the tree matter as dried blood becomes reused later in the novel when Annie is describing her period experiences. Annie reveals " $i$ remember...my secret pleasure, feeling the flow, a sudden rush of blood slide out between my lips and onto the pad" (90). The act of menstruation becomes a type of expression, a way of speaking that is inherently female, and can't occur with men. This becomes a way for women to write themselves into existence and to inscribe their mark on the pad (notepad?).

The discussion of women writing themselves into existence is problematic for many of the female characters in Ana Historic largely due to women's alienation from their respective bodies through the process of bodily industrialization. Marlatt expresses Annie's experience with Ina as "the body that defeats the self. the body, not even your 
body. split off, schizophrenic, suffering hysteric malfunction. all of this contained, unspoken but sounded in the shame with which you handed me my first box of pads" (89). Ina's feeling of shame contrasts Annie's joy regarding her menstruation, and the blood-like description of the tree matter. Ina cannot participate in a female community that celebrates menstruation because she has been corrupted by the split between head and body caused by the progression into womanhood. Annie remarks "that child, one with her body, not yet riven, not split in-two the self and the body that betrays the self" (89). The child's body is united because it does not yet possess the ability to be used for the purposes of generating offspring, and has not yet been moulded by male influence. Marlatt's description of the forest spaces inhabited by girls playing demonstrates a wholeness in that trees have not yet succumbed to the split by men's axes, and been transformed into stumps and logs. It is within the confines of this unsevered, uncut forest that Marlatt depicts Annie as a young girl remarking "our bodies were ours as far as we knew... without history we squatted in needle droppings to pee, flung our bodies through the trees" (19). The Cartesian mind-body split of the women in this novel, and the felling and splitting of the trees occurs at the site of production; the sawmill. The industry of logging and the discussion of menstruation is when the patriarchal modes of production begin to condition what women's bodies and the environment should be used for. Menstruation starts the process whereby women become able to provide offspring, creating a use for a woman that extends beyond their domestic capabilities. Men begin to recognize that trees are capable of providing resources, and women are capable of bearing their children. The male-function begins to assume control over these two spaces as harvesting resources necessary to further their capital. The mal(e)function is the reactionary response to the two different fetishes operating simultaneously. McClintock posits that

following Freud, fetishism has been relegated primarily to the "private" realm of domestic space (conventionally the domain of psychoanalysis), while commodity 
fetishism has been relegated primarily to the "public" realm of market space (conventionally the domain of male socio-economic history)...the fetish stands at the cross-roads of psychoanalysis and social history, inhabiting the threshold of both personal and historical memory. (184)

The coining of the term mal(e)function not only refers to the linguistic representations of women, but how they are traced alongside a history that encapsulates both psychoanalytic and commodity fetishism.

This analogy can be extended further to highlight the implications for commodities in the interest of a presiding patriarchal force. Karl Marx explains the relationship of values in the following way: "A commodity presented itself to us as a complex of two things-use-value and exchange-value. Later on, we saw also that that labour, too, possesses the same two-fold nature; for, so far as it finds expression in value, it does not possess the same characteristics that belong to it as a creator of use-values" (48). What this creates is a division between that which creates the value of something and that which becomes the product which is then exchanged. Marx's definition highlights the deep ideological differences that divide the industrializers and the industrialized. The mal(e)function serves to measure the mechanization of women in the interest of producing children (which by larger extension could be considered capital), as well as demonstrating the psychoanalytic underpinnings of the ecriture feminine in its malfunction of this male industrialization. The function of the forest is also subjected to male mechanization through the process of logging. The forest gives itself over to male production until it is so completely transformed by the men of industry that it ceases to be wood and forest, and becomes tables and logs instead. This is what occurs to the women in Ana Historic unless they resist the complete transformation as Ana, Annie and Ina attempt to do. Understanding how/what the end result of women and these forest spaces is involves investigating the process of production which begins with the sawmill. Marlatt brings different representations of trees into dialogue with each other when she 
begins to describe the dismantling of the natural forest space. The first stage of production is the cutting down of the tree itself, which in turn, relates to the Cartesian model of mind-body severance that occurs to the women in Ana Historic at puberty. Mrs. Richards wants to lose "her English self she wanted to lose in the trees, trees we have already lost. trees so big men lay inside the gash their axes left and the tree still standing, still joined to part of itself, so big men balanced on boards wedged in the trunk to cut it down, or had pictures made of themselves standing victorious on top of the fallen length" (20-21). Marlatt's imagery of the axe lying in the gash clearly sets up the idea of the male phallic object either being thrust into the women's vagina, or the leaving of his seed and violence within her vaginal walls. The cutting of the trees and the severing of women's bodies all contribute to the same industrial end goal that supersedes any other goals or priorities.

In Ana Historic, the logging stage of forest production correlates with the production of women into civilized creatures that are suitable for marriage and childrearing. Women are beginning to enter into the male sphere of production, and must be properly conditioned to accept such a position. Annie imagines the ladies of Hastings Mill as believing that "a decent lady kept herself well-covered, her sexuality hidden. no flag to taunt 'vigorous' men with. for if men couldn't control their desires, women could. women knew the standard of what was socially acceptable in conduct and apparel" (33). Women are conditioned through other women to behave appropriately when it comes to men. The social conditioning of women for men becomes a type of inheritance from their mothers. In this regard, women assist in upholding the male-function as they prepare their daughters suitably for becoming wives.

Marlatt continues the discussion of the trees in the second stage of production when she references the sawmill. Sawdust is the by-product of the mill's production of lumber and logs, and it permeates the novel as a tangible presence of a remnant of something that is already made, or has been destroyed. This point is emphasized when 
Marlatt describes Mrs. Richard's arrival at the Hastings Mill settlement as "walking into sawdust" (21). Marlatt sets up Ana Richards up as entering a sphere that is becoming preoccupied with the manufactured. Hastings Mill is the locus of the settlement, and is founded on resource extraction. The sawdust creeps into the novel in the spaces that represent submission to the dominant male control. The sawdust provides the necessary path that people must walk on in order to get to this ordered version of family and womanhood. Ina informs Annie that "real life had to do with bills and snow, with sawdust and fever thermometers and bargain clothes" (98). Sawdust is an inevitable part of the normal functioning of products assimilated into culture. The sawdust is the byproduct of industry much in the same way that children are the product of proper female functioning under male control.

The final stage of forest production (and arguably the most important) is the creation of logs, and what they will be used for. Once the mill has shaved down the trees and fashioned organized planks of wood, the trees cease to resemble trees, but instead resemble goods such as lumber. The forest has submitted itself completely to malefunctions and is now transformed into something unrecognizable from its initial state. Marlatt sets up this transitional imagery of the forest to demonstrate to women the pitfalls of readily submitting their agency to those in power. The final production is when women like Ana, Ina and Ana begin to resist the linear progression of male capital history in favour of creating their own pockets of female space. The more that these three female characters begin to identify with the spaces created in the absence of men, they more they begin to malfunction, creating the monster of mal(e)functions of their socialized malefunctions. The female protagonists must pit themselves against men (and women who have already been manufactured by men) to varying levels of success. Marlatt's women must repair the severance between the body and the mind if they are to resist a fate similar to the forest. This involves acting out, and against, the larger manufactured female community in the search for an authentic female identity not conditioned by what women 
are useful to men for.

Ana fails at womanhood because she fails to adhere to what men describe as the virtues necessary for possessing it. Paradoxically, Ana describes Jeannie Alexander as "all belly, preceded by it, as if by a monstrous assertion in the world" (116). The assertion that precedes Jeannie's body is one that is no longer her own, but an assertion that men's resource (or seed) must make itself known to the world. Marlatt describes Jeannie Alexander as "lumbered with the weight of pregnancy" (70 emphasis mine). Jeannie's body has been transformed into lumber, a resource that yields capital and signifies progress. Annie writes Ana Richards into existence because she is not satisfied with the notion that "history married her to Ben Springer and wrote her off" (134). In this sense, Annie creates the monster in Ana because she refuses to believe that Ana is a mere function of a male entity.

Ina fleetingly imagines a world without children, a space of absence that she creates through her disavowal of the mother duties outlined for her. Ina does not possess the tools necessary to manipulate the patriarchal constructs that keep her confined to her house "where your [Ina's] place was, with the sawdust furnace, with the wood stove for heat" (137). The presence of wood that exists around Ina is either completely manufactured or destroyed. The use of manufactured resources imitates the way that Ina gets used as the bearer of children and the proper wife. Ina is herself manufactured, and in the end, her own manufactured identity is what causes her downfall. Ina cannot distance her individual identity absent of its representation in the male sphere. It becomes the art of the manufacture, the plasticity of the resource that sets it apart from the real. Just as the wood becomes unrecognizable, Ina cannot go back and reclaim her original self from the new one. The monster becomes the complete separation from male-ordered domesticity, and functions as the empowered women. It is only a monster insofar as it challenges the gendered norm, as something previously unrecognized.

The monster becomes the reactionary embodiment of women refusing to be 
processed by the overarching male force. Women have continued to fight for equal rights and freedoms through a number of feminine discourses. While environmental groups tend to "speak for the forest" in order to protect it from environmental crisis, this poses its own unique set of challenges. As seen in Ana Historic, men who use land for their own purposes, even while claiming environmental altruism, still implicate themselves in a tradition of industrialization. Revisiting Ana Historic with mal(e)functions in mind helps highlight the trouble that phallocentric environments create for women and the environment. Marlatt describes Annie's experience of history; "i learned that history is the real story the city fathers tell of the important events in the world. a tale of their exploits hacked out against a silent backdrop of trees, of wooden masses" (28). Masculinity has silenced the forest spaces in their colonization of the landscape, they will not do the same to the story that Annie will tell about Ana Richards. The key to environmental and feminine spaces resides in the simultaneity of mal(e)functions, in the recognition that there may never be a women's history absent of a male one, but that histories can be contested and challenged in the same way that forests can be replanted and re-imagined; hopefully.

\section{Works Cited}

Bruce, Braun. The Intemperate Rainforest. Minneapolis: Minnesota UP, 1998. Print. Cixous, Hélène. The Newly Born Woman. Trans. Betsy Wing. Minneapolis: Minnesota UP, 1986. Print.

Gilbert, Sandra. Feminist Theory and Criticism: A Norton Reader. New York: Norton, 2006. Print.

Grainger, M. Allerdale. Woodsmen of the West. 1908. Toronto: M\&S, 1996. Print. Green, Keith and LeBihan, Jill. “The Speaking Object: Marlatt's Pronouns and Lesbian 
Politics.” Style 28.3 (Fall 1994): 432-45. Print.

Hodgins, Jack. Broken Ground. Toronto: M\&S, 1998. Print.

Lacan, Jacques. "The Signification of the Phallus." Trans. Alan Sheridan. Écrits: A

Selection. New York:

Norton, 1977. Print.

Marlatt, Daphe. Ana Historic. 1988.Toronto, House of Anansi Press, 2004. Print.

Marx, Karl. Capital: A Critique of Political Economy. $1867.4^{\text {th }}$ ed. 2 vols. Trans. by

Samuel

Moore. Ed. Frederick Engels. New York: Modern Library, 1906. Print.

McClintock, Anne. "Psychoanalysis, Race and Female Fetishism.” Imperial Leather-

Race

Gender, and Sexuality in the Colonial Contest. UK: Routledge, 1995. Print.

Plumwood, Val. Feminism and the Mastery of Nature. New York: Routledge, 1993.

Print.

Whitford, Margaret. The Irigaray Reader. UK, Basil Blackwell, 1991. Print. 
